\title{
PERATURAN MAHMAKAH AGUNG NOMOR 2 TAHUN 2015 TENTANG TATA CARA PENYELESAIAN GUGATAN SEDERHANA SEBAGAI INSTRUMEN PERWUJUDAN ASAS PERADILAN SEDERHANA, CEPAT DAN BIAYA RINGAN
}

\author{
Shanti Riskawati \\ eugene_r03@yahoo.com
}

\begin{abstract}
Abstrak
Tujuan penelitian ini untuk mengetahui apakah Perma No. 2 Tahun 2015 telah mencerminkan asas peradilan sederhana, cepat biaya ringan dan kelemahan Perma tersebut. Hasil menyimpulkan bahwa Perma tersebut sebagai salah satuinstrumen penerapan asas peradilan sederhana, cepat, biaya ringan. Hal tersebut ditandaidengan beberapa pengaturan yang membedakan dengan gugatan perdata umum, antara lain:Pemeriksaan gugatan sederhana dilakukan hakim tunggal, para pihak dalam gugatansederhana tidak boleh lebih dari satu dan berdomisili di daerah hukum Pengadilan yang sama,pemeriksaan gugatan sederhana hanya 25 hari. Kelemahan PERMA ini ialah: Para pihak tidak dalam domisili hukum yangsama, dalam mengajukan gugatan sederhana, para pihak bisa diwakili oleh kuasa hukum,yurisdiksi gugatan sederhana hanya pada peradilan umum, tidak menjangkauPengadilan Agama, kdudukan hakim tunggal berpotensi mempengaruhi subyektifitas hakim, tidak diatur tentang konsekuensi ketika putusan melebihi waktu 25 hari, belum ada ketentuan yang jelas mengenai pembuktian sederhana, tidak diperkenankannya eksepsi sertabelum ada ketentuan mengenai sita jaminan.
\end{abstract}

Kata Kunci: Gugatan Sederhana, Asas Peradilan Sederhana, Cepat dan Biaya Ringan.

\begin{abstract}
The objective of this present research is to understand whether Supreme Court Regulation No. 2 year 2015 has reflected simple judicial principle, quick and low cost and the weaknesses of the regulation. From the results it can be concluded that the Supreme Court Regulation merely served as one of the instruments in the application of the simple court, quick, and low cost principle where it can be marked from some regulations distinguishing it from general civil lawsuit namely among others: the lawsuit examination was made a single judge, the parties in the simple lawsuit were not allowed to be more than one and his/her domicile shall be in the same territory of the court and the lawsuit examination shall not be more than 25 days. The weaknesses of the Supreme Court Regulation were as follows: the parties involved do not have domiciles in the same jurisdiction, in filling the simple lawsuits, the parties may be represented by their attorneys, the jurisdiction of the simple lawsuit is merely for general justice, it does not cover the religious courts, the position of single judge potentially influences his/her subjectivity, no stipulation is made for the consequence when the decision made exceeds 25 days, no clear stipulation exists about the simple proof, no exception is allowed before there is stipulation on the confiscation of guarantee.
\end{abstract}

Key Words: Simple lawsuit, Simple judicial principle, quick and low cost 


\section{PENDAHULUAN}

Dalam pergaulan bisnis yang dilakukan tersebut, baik yang dilakukan oleh Negara maupun orang per orangan dan entitas bisnis lainnya, tidak menutup kemungkinan akan terjadi sengketa antara para pihak yang terlibat. Setiap jenis sengketa yang terjadi selalu menuntut pemecahan dan penyelesaian secara cepat dengan hasil penyelesaian yang mampu memenuhi rasa keadilan kedua belah pihak.

Pada dasarnya, mekanisme penyelesaian sengketa bisnis, dapat dilakukan baik melalui pengadilan maupun melalui proses di luar pengadilan. Penyelesaian sengketa melalui Pengadilan dianggap tidak efektif dan efisien, tidak menghasilkan kepastian hukum serta ada kalanya tidak mencerminkan rasa keadilan, terlebih lagi kredibilitas para pelaku bisnis juga akan tercoreng dengan tereksposnya pemeriksaan peradilan tersebut. Bagi pelaku bisnis yang menganut asa time is money, proses peradilan yang lambat dan berbelit-belit tentunya bukan menjadi pilihan yang baik. Lambatnya proses peradilan adalah dikarenakan system peradilan kita yang berjenjang.Berdasarkan hasil penelitian Bank Dunia (The world Bank-International Finance Corporation-Doing Business 2011) tentang Lambatnya Peroses Penyelesaian Sengketa Bisnis di Indonesia dinyatakan bahwa terdapat beberapa sebab, sebagai berikut $:^{1}$
a. Penyelesaian sengketa pada pengadilan tingkat pertama yang tidak efisien
b. Jangka waktu penyelesaian yang lama

${ }^{1}$ Bustamar, Small Claim Court dalam Hukum Acara Perdata di Indonesia, diakses tanggal 15 Maret 2017, pukul 14.30 WIB.

\section{c. Biaya perkara yang tinggi \\ d. Serta biaya pengacara yang tinggi}

Bertitik tolak pada pemaparan di atas, maka dirasakan perlu adanya suatu bentuk prosedur penyelesaian sengketa khususnya bisnis, seperti yang dikenal di negara-negara yang menganut sistem common law dengan memberikan kewenangan pada pengadilan untuk menyelesaikan perkara didasarkan pada besar kecilnya nilai objek sengketa,sehingga dapat tercapai penyelesaian sengketa (bisnis) secara cepat, sederhanadan murah, melalui mekanisme yang dinamakan Small Claim Court.

Selain alasan di atas Small Claim Court sangat dibutuhkan bagi penyelesaian sengketa yang timbul dalam transaksi bisnis yang dilakukan oleh pengusahan mikro, kecil dan menengah (UMKM). Perkembangan UMKM di Indonesia terus meningkat, krisis keuangan global mengintensifkan fokus kebijakan pada usaha kecil dan menengah sebagai penggerak pertumbuhan ekonomi.

Menyikapi kondisi tersebut Mahkamah Agung (MA) telah menerbitkan Perma Nomor 2 Tahun 2015 tentang Tata Cara Gugatan Sederhana atau disebut Small Claim Court, gugatan perdata ringan dengan proses penyelesaian cepat. Terbitnya PERMA ini dalam rangka menyongsong era perdagangan bebas ASEAN 2015 yang diprediksi akan banyak menimbulkan sengketa perkara-perkara niaga/bisnis skala kecil yang berujung ke pengadilan.

Ketua Mahkamah Agung menyatakan bahwa PERMA ini terbit untuk mempercepat proses penyelesaian perkara sesuai asas 
peradilan sederhana, cepat, biaya ringan. Hal tersebut dikarenakan, selama ini masyarakat pencari keadilan masih mengeluhkan lamanya proses berperkara di pengadilan. Indonesia menjadi sorotan masyarakat ekonomi dunia karena tidak memiliki small claim court. Karena itu, MA menerbitkan PERMA Small Claim Court ini dalam upaya mewujudkan negara demokrasi modern dan meningkatkan pelayanan terbaik bagi masyarakat pencari keadilan² Terbitnya PERMA ini juga salah satu cara mengurangi volume perkara di MA.

Akan tetapi secara substansi ada beberapa permasalahan dalam norma ini, beberapa hal tidak diatur secara jelas hukum acaranya atau bahkan menyimpangi asasa yang selama ini lazim digunakan dalam hukum acara perdata. Misalnya terkait dengan ketentuan bahwa untuk suatu perkara bisa diselesaikan menggunakan mekanisme gugatan sederhana, maka para pihak, Penggugat dan Tergugat harus tinggal dalam satu wilayah/yuridiksi Pengadilan yang sama. Hal ini akan mempersulit para pihak yang kebetulan tidak tinggal di wilayah hukum Pengadilan yang sama akan tetapi secara substansi lainnya seharusnya perkara mereka seharusnya bisa diselesaikan secara sederhana. Dalam Perma ini juga memangkas beberapa tertib acara persidangan yang bisa menimbulkan potensi berkurangnya hak para pihak. Bertitik tolak dengan keadaan tersebut maka penulis dalam penelitian ini ingin mengkaji dan menelaah lebih jauh substasi dalam Perma No. 2 Tahun 2015 ini serta

${ }^{2}$ Urgensi Terbitnya Perma Small Claim Court, Hukumonline.com, diakses pada tanggal 15 Maret 2018, pukul 14.30 WIB. relevansinya dengan asas Persidangan

Seerhana, Cepat dan Biaya Ringan.

\section{RUMUSANMASALAH}

1. Apakah Gugatan sederhana sebagaimana diatur dalam Perma Nomor 2 Tahun 2015 telah mencerminkan asas peradilan Sederhana, Cepat dan Biaya Ringan dalam Hukum Acara Perdata di Indonesia?

2. Apakah kelemahan substansi dalam Perma Nomor 2 Tahun 2015 ?

\section{PEMBAHASAN}

Perma 2 Tahun 2015 Tentang Gugatan Sederhana Sebagai Salah Satu Instrumen Dalam Menerapkan Asas Sederhana, Cepat, Biaya Ringan

1. Analisa Asas Peradilan Sederhana, Cepat, Biaya Ringan

Asas (prinsiple) merupakan hal yang dapat dijadikan sebagai alas, sebagai dasar, sebagai tumpuan, sebagai pokok pangkal, sebagai fundamen. Asas (prinsiple) adalah sesuatu yang dapat dijadikan alas, sebagai tempat untuk menyandarkan, untuk mengembalikan sesuatu hal yang hendak dijelaskan.

Dalam menjalankan fungsinya, Kekuasaan Kehakiman selain melaksanakan fungsinya "Demi Keadilan Berdasarkan Ketuhanan Yang Maha Esa" juga dilakukan dengan sederhana, cepat dan biaya ringan. Pasal 2 ayat (4) Undang-Undang Nomor 48 Tahun 2009 Tentang Kekuasaan Kehakiman dinyatakan bahwa peradilan dilakukan dengan sederhana, cepat dan biaya ringan. Selanjutnya dalam penjelasannya diuraikan bahwa peradilan harus 
memenuhi harapan para pencari keadilan yang selalu menghendaki peradilan dilakukan dengan sederhna, cepat, tepat, adil dan biaya ringan, tidak diperlukan pemeriksaan dan acara yang berbelit belit yang dapat menyebabkan proses sampai bertahun-tahun, bahkan terkadang sampai harus dilanjutkan oleh ahli waris para pihak. Ketentuan ini dimaksudkan untuk memenuhi harapan pencari keadilan.

Sederhana bermakna pemeriksaan dan penyelesaian perkara dilakukan dengan cara efisien dan efektif dengan cara atau prosedur yang jelas, mudah dimengerti, dipahami dan tidak rumit atau tidak berbelit-belit. Makin sedikit dan sederhana formalitas-formalitas yang diwajibkan atau diperlukan dalam beracara di pengadilan semakin baik. Banyaknya formalitas dan tahapan-tahapan yang harus ditempuh yang sulit untuk dipahami akan menimbulkan berbagai penafsiran atau pendapat yang tidak seragam, sehingga tidak akan menjamin keragaman atau kepastian hukum yang ada pada gilirannya akan menyebabkan keengganan atau ketakutan untuk beracara di muka pengadilan. ${ }^{3}$

Keserdehanaan beracara dan keserhanaan peraturan-peraturan hukum acara akan mempermudah, sehingga akan mempercepat jalannya peradilan. kesederhanaan berarti kesederhanaan prosedur peradilan yang tidak berbelit-belit atau formalitas-formalitas. Kesederhanaan rumusan berarti rumusan peraturan yang menggunakan bahasa hukum yang sederhana dan mudah dipahami tanpa meninggalkan bahasa hukum yang tepat.

Prosedur menurut H.I.R dan RBg tidaklah menghendaki syarat-syarat yang berat bagi suatu perumusan tuntutan, tidak diliputi formalitas. Prosedur HIR dan RBg dapat dikatakan sederhana dan memperhatikan tingkat kecerdasan mereka yang hendak menuntut keadilan, sehingga dengan tuntutan yang sifatnya sederhana pun cukup, sebagaimana yang pernah diputus oleh hakim, yang dianggap memenuhi syarat-syarat, suatu perumusan tuntutan yang berbentuk hanya katakata "mohon keadilan"4. Hal ini tidak mengherankan, ditinjau dari sudut Pasal 178 ayat (1) HIR dan Pasal $189 \mathrm{RBg}$, yang memberikan kewajiban kepada hakim, dalam bermusyawarah dan sebelum mengambil keputusan, menambah dan mepertimbangkan suatu perkara, dasar-dasar hukum yang dikemukakan oleh kedua belah pihak, dengan dasar-dasar hukum lain yang tidak dikemukakan oleh orang-orang yang berperkara.

M. Yahya Harahap, memberikan penjelasan yang lebih tegas tentang makna dan arti peradilan sederhana, cepat dan biaya ringan. Menurut beliau, yang dicita-citakan dari peradilan sederhana, cepat dan biaya ringan adalah suatu proses pemeriksaan yang relatif

\footnotetext{
${ }^{4}$ Dwi Rezki Sri Astarini, "Mediasi Pengadilan, Salah Satu Bentuk Penyelesaian Sengketa Berdasarkan Asas Peradilan Cepat, Sederhana, Biaya Ringan”, Alumni, Bandung, 2013, hlm. 56.
} 
tidak memakan jangka waktu yang lama sesuai dengan kesederhanaan hukum acara itu sendiri. ${ }^{5}$

Proses beracara dan pemeriksaan di Pengadilan harus berjalan dengan sederhana, cepat dan biaya rinngan, tetapi tidak boleh mengurangi ketepatan pemeriksaan dan penilaian terhadap hukum dan keadilan. Kederhanaan, kecepatan pemeriksaan, tidak boleh dimanipulasi untuk membengkokkan hukum, kebenaran dan keadilan. Semua harus tepat menurut hukum.

Penggugat yang ingin mengajukan perkara Gugatan Sederhana, sebagaimana dalam perkara perdata pada umumnya, wajib mendaftarkan ke kepaniteraan di Pengadilan. Berbeda dengan perkara perdata umumnya, dalam gugatan sederhana, Penggugat cukup mengisi form yang sudah disediakan di pengadilan. Form tersebut berisikan :

a. Identitas Penggugat dan Tergugat

b. Penjelasan ringkas duduk perkara

c. Tuntutan Penggugat

"Biaya ringan" adalah biaya perkara yang serendah mungkin, sehingga dapat dipikul oleh masyarakat. Meskipun demikian, dalam pemeriksaan dan penyelesaiaan perkara tidak mengorbankan ketelitian dalam mencari kebenaran dan keadilan.

Biaya perkara yang tinggi akan membuat orang enggan untuk berperkara di pengadilan, mengenai biaya ringan dalam berperkara merupakan hal yang diidam-idamkan oleh para pihak. Hal tersebut rasional, jika dilihat seseorang ingin menuntut haknya namun masih

5 Yahya Harahap, "Kedudukan Kewenangan dan Acara Peradilan Agama", Pustaka Kartini, Jakarta 1993, hlm. 54. dibebani biaya yang tinggi, meskipun di sisi lain soal menuntut atau tidak terserah kepada pihak yang bersangkutan. Hal tersebut sesuai dengan asas bahwa berperkara harus dikenai biaya, akan tetapi jika disesuaikan dengan asas biaya ringan, maka seyogyanya Pengadilan juga tidak menetapkan biaya perkara yang sangat tinggi. Karena biaya perkara yang tinggi akan menyebabkan kebanyakan pihak yang berkepentingan enggan untuk mengajukan tuntutan hak kepada pengadilan.

"Peradilan Cepat" adalah menyangkut jalannya peradilan dengan ukuran waktu atau masa acara persidangan berlangsung. Hal ini berkaitan dengan masalah kesederhanaan prosedur atau proses persidangan diatas. Apabila prosedurnya terlalu rumit akan berakibat memakan waktu yang lebih lama. Penyelesaian perkara yang memakan waktu terlalu lama berpotensi akan menimbulkan masalah-masalah baru, misalnya berubahanya kondisi atau keadaan objek sengketa yang tentunya akan membawa pengaruh pada saat eksekusi dilakukan nantinya.

Berdasarkan Surat Edaran Mahkamah Agung R.I. Nomor 6 Tahun 1992 Tentang Penyelesaian Perkara di Pengadilan Tinggi dan Pengadilan Negeri tanggal 21 Oktober 1992, ditetapkan oleh Mahkamah Agung R.I, tenggang waktu penyelesaian paling lambat 6 (enam) bulan dengan ketentuan apabila tenggang waktu tersebut terlampaui harus melaporkan keterlambatan kepada Pengadilan Tinggi dan Mahkamah Agung R.I.

Jangka waktu yang pantas, artinya bahwa hakim menjaga agar tidak terjadi keterlambatan yang tidak pantas atau pelaksanaan prosedur, 
maka atas permintaan para pihak atau atas dasar jabatannya, hakim dapat mengambil tindakantindakan untuk mempercepat prosedur yang dimaksud.

Asas-asas sebagaimana dijelaskan diatas dan diimplementasikan oleh Mahkamah Agung melalui Perma Gugatan Sederhana, sejatinya sejalan dengan hasil konsorsium tentang "International Framework of Court" yang menghasilkan 7 (tujuh) bidang keutamaan diantaranya point ke-3 adalah "Court Proccedings", dimana dimaknai bahwa peradilan yang unggul adalah :

"fair, effective dan efficient court proceeding are indicators is court excellence. Efficient and court proceeding also require a sound division of labour between judges and court staff. Excellent courts have fair, efficient and effective court proceedings"

Adil, tepat guna, dan berdaya guna merupakan ciri-ciri peradilan yang unggul, hal ini sejalan dengan asas-asas peradilan yang baik dalam sistem peradilan di Indonesia yang menyatakan setiap orang berkedudukan sama di depan hukum, peradilan dilaksanakan secara tepat waktu, terjadwal dengan baik, tidak berbelit-belit sehingga bisa menghindari pemborosan biaya. Meskipun tidak disebut dengan kata cepat, makna kata tepat efektif dan efisien adala tepat waktu dan tepat guna dengan kata lain tidak membuang kesempatan lain, selain untuk proses persidangan biaya yang harus dikeluarkan juga menjadi hemat, tidak mahal dan terjangkau.

2. Analisa Perma No. 2 Tahun 2015 Sebagai Salah Satu Instrumen
Penerapan Asas Peradilan Sederhana,

\section{Cepat, Biaya Ringan.}

Pasal 4 ayat (2) UU No. 4 Tahun 2004 Tentang Kekuasaan Kehakiman menyatakan bahwa Pengadilan membantu pencari keadilan dan berusaha mengatasi segala hambatan dan rintangan untuk dapat tercapainya peradilan yang sederhana, cepat dan biaya ringan. Dengan dikeluarkannya Perma Nomor 2 Tahun 2015, menjadi salah satu terobosan Mahkamah Agung dalam mengurangi penumpukkan perkara. Selain itu Mahkamah Agung juga menyempurnakan prosedur mediasi di Pengadilan yang sebelumnya diatur dalam Perma Nomor 1 Tahun 2008, saat ini sudah diperbaharui dengan Perma Nomor 1 Tahun 2016. Berikut beberapa karakter dalam Perma Nomor 2 Tahun 2015 yang berbeda dengan Gugatan Perdata Umum, antara lain:

a. Gugatan sederhana merupakan gugatan perdata dengan nilai gugatan materiil paling banyak $\mathrm{Rp}$ 200.000.000,00 (dua ratus juta rupiah) yang diselesaikan dengan tata cara dan pembuktian yang sederhana. Penyelesaian dengan gugatan sederhana hanya bisa digunakan untuk perkara ingkar janji (wanprestasi) dan/atau Perbuatan Melawan Hukum (PMH). ${ }^{6}$ Namun demikian, tidak semua perkara ingkar janji dan PMH dapat diselesaikan melalui penyelesaian gugatan sederhana. Perkara

\footnotetext{
${ }^{6}$ Lihat pasal 3 ayat (1) Perma Nomor 2 Tahun 2015 Tentang Tata Cara Penyelesaian Gugatan Sederhana.
} 
yang tidak dapat diselesaikan melalui mekanisme ini antara lain: ${ }^{7}$

1) Perkara yang penyelesaian sengketanya dilakukan melalui pengadilan khusus sebagaimana diatur di dalam peraturan perundang-undangan, seperti persaingan usaha sengketa konsumen dan penyelesaian perselisihan hubungan industrial

2) Perkara yang berkaitan dengan sengketa hak atas tanah

b. Pemeriksaan gugatan sederhana dilakukan oleh hakim tunggal sebagaimana diatur dalam Ketentuan Umum Pasal 1 angka 3 Perma Nomor 2 Tahun 2015.

c. Para pihak dalam gugatan sederhana tidak boleh lebih dari satu dan berdomisili di daerah hukum Pengadilan yang sama. ${ }^{8}$

Para Pihak dalam gugatan sederhana harus memenuhi kriteria sebagai berikut :

a. Masing-masing satu penggugat dan tergugat yang merupakan orang perseorangan atau badan hukum. Penggugat maupun tergugat dapat lebih dari satu apabila memiliki kepentingan hukum yang sama; ${ }^{9}$

${ }^{7}$ Lihat Pasal 3 ayat (2) Perma Nomor 2 Tahun 2015 Tentang Tata Cara Penyelesaian Gugatan Sederhana.

${ }^{8}$ Lihat Pasal 4 ayat (1) Perma Nomor 2 Tahun 2015 Tentang Tata Cara Penyelesaian Gugatan Sederhana

${ }^{9}$ Yang dimaksud dengan kepentingan hukum yang sama adalah kepentingan yang saling terkait antara sesama Penggugat atau Tergugat. Sebagai contoh, dalam perjanjian kredit, suami yang menandatangani perjanjian kredit yang dilakukan oleh istri merupakan pihak yang masuk dalam kategori kepentingan hukum yang sama dalam sengeketa perdata tersebut. b. Terhadap Tergugat yang tidak diketahui tempat tinggalnya tidak dapat diajukan melalui gugatan sederhana

c. Penggugat dan Tergugat berada dalam daerah hukum yang sama.

Pemeriksaan gugatan sederhana hanya dalam tempo 25 hari $^{10}$ oleh hakim tunggal dengan tahapan sebagai berikut :

a. Pendaftaran;

Gugatan didaftarkan di kepaniteraan pengadilan di daerah hukum para pihak, yang dibuktikan dengan kartu tanpa penduduk (KTP). Penggugat wajib memastikan bahwa pihak Tergugat berada di daerah hukum yang sama dengan Penggugat dan jelas alamat tempat tinggalnya. Penggugat dapat mengajukan gugatan secara mandiri dengan mengisi blanko gugatan berupa Formulir Gugatan Sederhana sebagaimana terdapat dalam Lampiran $3^{11}$ Formulir Gugatan Sederhana yang tersedia di kepaniteraan pengadilan negeri setempat. Selain mengisi blanko gugatan, Penggugat juga sudah harus siap dengan bukti surat yang sudah dilegalisasi. Setelah gugatan didaftarkan, maka para pihak menunggu panggilan dari pengadilan. Petugas pengadilan akan mencatat gugatan tersebut dalam buku register khusus gugatan sederhana.
b. Pemeriksaan kelengkapan gugatan sederhana;
c. Penetapan hakim dan penunjukkan panitera pengganti;

${ }^{10}$ Lihat pasal 5 Perma Nomor 2 Tahun 2015

Tentang Tata Cara Penyelesaian Gugatan

Sederhana.

${ }^{11}$ Lihat lapiran 3 Formulir Gugatan Sederhana 
Setelah dicatatkan, berkas gugatan yang dimaksud akan diserahkan kepada ketua pengadilan. Ketua pengadilan menunjuk hakim yang akan memeriksa dan memutus perkara aquo.

d. Pemeriksaan pendahuluan;

Apabila hakim berpendapat bahwa gugatan tidak termasuk dalam gugatan sederhana, maka hakim mengeluarkan penetapan yang menyatakan bahwa gugatan bukan gugatan sederhana, mencoret dari register perkara dan memerintahkan pengembalian sisa biaya perkara setelah dipotong biaya-biaya yang dikeluarkan oleh pengadilan, di antaranya, biaya panggilan dan biaya-biaya lainnya yang sudah dikeluarkan kepada Penggugat.

Jika gugatan dinyatakan bukan gugatan sederhana, bukan berarti hak Penggugat untuk mendapatkan keadilan menjadi hilang. Penggugat dapat mengajukan gugatan ke dalam gugatan biasa. Apabila hakim berpendapat bahwa gugatan yang diajukan penggugat adalah gugatan sederhana, maka hakim menetapkan hari sidang pertama. Baik penggugat maupun tergugat akan dipanggil oleh pengadilan untuk hadir pada sidang pertama.

e. Penetapan hari sidang dan pemanggilan para pihak;

Pihak (penggugat dan tergugat) berdasarkan data yang ada dalam Formulir Gugatan Sederhana. Pastikan bahwa data yang terdiri dari nama, umur dan alamat tergugat terisi dengan lengkap.

Panggilan dilakukan oleh jurusita ke alamat yang tertera di dalam formulir gugatan. Pemberitahuan terkait informasi sidang dapat juga dilakukan melalui pesan teks (SMS) ataupun surat elektronik (Email) yang anda cantumkan dalam formulir gugatan.

f. Pemeriksaan sidang dan perdamaian;

Dalam persidangan hari pertama, hakim akan mengupayakan perdamaian antara para pihak. Perdamaian adalah ketika penggugat dan tergugat mencapai kesapakatan penyelesaian perkaranya secara sendiri oleh pihak, tanpa diputuskan oleh hakim. Apabila perdamaian tercapai, maka hakim akan membuat Putusan Akta Perdamaian. Terhadap Putusan Akta Perdamaian yang bersifat final dan mengikat, baik tergugat ataupun penggugat tidak dapat mengajukan upaya hukum.

Apabila perdamaian tidak tercapai, maka hakim akan mulai mendengarkan gugatan yang disampaikan oleh penggugat dan jawaban dari tergugat. Apabila tergugat tidak membantah gugatan yang diajukan, maka tidak akan ada proses pembuktian. Hakim akan memutus berdasarkan apa yang diajukan oleh penggugat.

Apabila tergugat membantah apa yang diajukan oleh penggugat, maka akan dilanjutkan dengan pembuktian. Hakim tidak akan mendukung salah satu pihak, dalam artian hakim memberikan informasi secara seimbang kepada kedua belah pihak.

g. Pembuktian;

Pembuktian dilakukan dengan cara sederhana. Dalam Perma ini tidak dijelaskan secara eksplisit apa yang dimaksud dengan pembuktian sederhana. Pembuktian adalah upaya yang dilakukan para pihak dalam berperkara untuk menguatkan dan membuktikan dalil-dalil yang diajukan oleh para pihak. Penggugat dapat mengajukan alat bukti yang sudah dipersiapkan sebelumnya. 
Dalam tahap pembuktian, para pihak khususnya Penggugat harus menjelaskan mengapa alat bukti yang diajukan itu penting.

Tahapan pembuktian ini yang akan menentukan putusan yang dibuat oleh hakim. Berbeda dengan pemeriksaan gugatan perdata umum, dimana para pihaklah yang menentukan apa yang hendak dibukikan, dalam Perma ini di tahap pembuktian, hakim dapat menentukan hal apa saja yang harus dibuktikan dari kedua belah pihak. Oleh karena itu, para pihak hanya perlu untuk mempersiapkan apa saja yang diminta oleh hakim untuk dibuktikan.

h. Putusan;

Setelah proses pembuktian selesai, hakim akan membuat putusan. Putusan diucapkan dalam persidangan yang terbuka untuk umumpada hari yang sama dengan pembuktian atau pada persidangan berikutnya. Setelah mengucapkan putusan, hakim akan memberitahukan hak-hak para pihak antara lain menerima atau menolak putusan.

d. Pemeriksaan gugatan sederhana diawali dengan pemeriksaan pendahuluan.

Pasal 11 gugatan sederhana mengatur tentang pemeriksaan pendahuluan. Pemeriksaan pendahulun tidak dikenal dalam perkara perdata, dimana dalam mekanisme gugatan sederhana tahab inilah yang menentukan suatu perkara itu dapat dikategorikan gugatan sederhana atau tidak. Hakim memeriksa pokok perkara atau materi gugatan sederhana dengan instrumen yang telah ditetapkan dalam pasal 3 dan 4. Dalam tahapan ini juga hakim menentukan sederhana atau tidaknya pembuktian. Jika hakim melalui pemeriksaan ini berpendapat bahwa gugatan yang diajukan tidak termasuk gugatan sederhana, maka Hakim mengeluarkan penetapan yang menyatakan bahwa gugatan bukan gugatan sederhana, kemudian mencoretnya dari register perkara dan memerintahkan pengembalian uang panjar perkara yang sudah dibayarkan oleh Penggugat. Terhadap penetapan ini tidak dapat diajukan upaya hukum apapun. Sebaliknya, jika Hakim berpendapat bahwa gugatan yang diajukan Penggugat masuk dalam kategori gugatan sederhana, maka Hakim menetapkan hari sidang pertama.

Pemeriksaan pendahuluan biasanya dikenal di Persidangan pada Pengadilan Tata Usaha Negara. Istilah yang digunakan untuk tahapan ini dalam Hukum Acara Pengadilan Tata Usaha Negara disebut Pemeriksaan Persiapan. Pemeriksaan Persiapan di PTUN wajib dilakukan. Pemeriksaan ini dihadiri oleh Penggugat dan Tergugat. Adapun tujuan dari pemeriksaan ini adalah untuk menyempurnakan penyusunan surat gugatan. Di pihak Penggugat, hadir untuk memperbaiki gugatannya dan jika diperlukan menambahkan data-data. Sedangkan di pihak Tergugat, hadir untuk memberikan keterangan yang diminta oleh Majelis Hakim dan memberikan data yang tidak dimiliki oleh Penggugat. Majelis Hakim PTUN tidak dapat menjatuhkan putusan menyatakan bukan sengketa Tata Usaha Negara meskipun dalam pemeriksaan itu ditemukan hal demikian.

Hal inilah yang membuat pemeriksaan pendahuluan dalam gugatan sederhana berbeda. Dalam pemeriksaan pendahuluan gugatan sederhana, pemeriksaan hanya dilakukan sendiri oleh Hakim, tidak dihadiri oleh Penggugat dan Tergugat. Hakim sifatnya adalah hanya memeriksa berdasarkan berkas yang ada. Dan jika Hakim berpendapat bahwa perkara yang diajukan tidak termasuk gugatan sederhana, maka Hakim berhak mengeluarkan penetapan yang menyatakan gugatan bukan termasuk gugatan sederhana.

e. Perma 2/2015 mengesampingkan PERMA

No. 1 Tahun 2008 Tentang Mediasi.

Pada hari sidang pertama, Hakim wajib mengupayakan perdamaian dengan memperhatikan batas waktu sebagaimana dimaksud dalam Pasal 5 ayat (3), yaitu pemeriksaan gugatan sederhana harus diselesaikan dalam jangka waktu 25 hari. Oleh 
karenanya upaya perdamaian dalam Perma ini mengecualikan ketentuan yang diatur dalam ketentuan Mahkamah Agung mengenai prosedur mediasi. Dalam hal tercapai perdamaian, Hakim membuat Putusan Akta Perdamaian yang mengikat para pihak. Terhadap Putusan Akta Perdamaian tidak dapat diajukan upaya hukum apapun. Dalam hal tercapai perdamaian di luar persidangan dan perdamaian tersebut tidak dilaporkan kepada Hakim, maka Hakim tidak terikat dengan perdamaian tersebut.

f. Para pihak tidak dapat mengajukan provisi, eksepsi, rekonvensi, intervensi, replik, duplik atau kesimpulan.

Dalam pasal 17 diatur Dalam proses pemeriksaan gugatan sederhana, tidak dapat diajukan tuntutan provisi, eksepsi, rekonvensi, intervensi, replik, duplik, atau kesimpulan.

g. Upaya hukumnya adalah keberatan.

Upaya hukum terhadap putusan gugatan sederhana sebagaimana dimaksud dalam Pasal 20 adalah dengan mengajukan keberatan. Keberatan diajukan kepada Ketua Pengadilan dengan menandatangani akta pernyataan keberatan di hadapan panitera disertai alasanalasannya. $^{12}$

Permohonan keberatan diajukan paling lambat 7 (tujuh) hari setelah putusan diucapkan atau setelah pemberitahuan putusan. Permohonan keberatan diajukan kepada Ketua Pengadilan dengan mengisi blanko permohonan keberatan yang disediakan di kepaniteraan. Permohonan keberatan yang diajukan melampaui batas waktu pengajuan sebagaimana dimaksud pada ayat (1) dinyatakan tidak dapat diterima dengan penetapan ketua pengadilan berdasarkan surat keterangan panitera. ${ }^{13}$ Pemberitahuan keberatan beserta memori keberatan disampaikan kepada pihak termohon keberatan dalam waktu 3 (tiga) hari sejak permohonan diterima oleh Pengadilan.

${ }^{12}$ Lihat Pasal 21 Perma Nomor 2 Tahun 2015 Tentang Tata Cara Penyelesaian Gugatan Sederhana.

${ }^{13}$ Lihat Pasal 22 Perma Nomor 2 Tahun 2015

Tentang Tata Cara Penyelesaian Gugatan Sederhana. sedangkan Kontra memori keberatan disampaikan kepada pengadilan paling lambat 3 (tiga) hari setelah pemberitahuan keberatan. ${ }^{14}$

Ketua Pengadilan menetapkan Majelis Hakim untuk memeriksa dan memutus permohonan keberatan, paling lambat 1 (satu) hari setelah permohonan dinyatakan lengkap. Pemeriksaan keberatan dilakukan oleh Majelis Hakim yang dipimpin oleh Hakim senior ${ }^{15}$ yang ditunjuk oleh Ketua Pengadilan. ${ }^{16}$ Segera setelah ditetapkannya Majelis Hakim, dilakukan pemeriksaan keberatan. Pemeriksaan keberatan dilakukan hanya atas dasar: ${ }^{17}$

a. putusan dan berkas gugatan sederhana;

b. permohonan keberatan dan memori keberatan; dan

c. kontra memori keberatan.

Dalam pemeriksaan keberatan tidak dilakukan pemeriksaan tambahan. Bagian Keempat Putusan Keberatan Pasal 27 Putusan terhadap permohonan keberatan diucapkan paling lambat 7 (tujuh) hari setelah tanggal penetapan Majelis Hakim.

Berbeda dengan upaya hukum dalam pemeriksaan perdata umum, dimana tersedia upaya hukum banding yang diajukan pada Pengadilan Tinggi dan kasasi yang diajukan pada Mahkamah Agung. Hal ini memberikan kontribusi lambatnya penangan perkara di Indonesia, terutama jika para pemangku profesi hukum seperti hakim dan advokat ikut bermain dalam suatu jalannya persidangan.

\section{Karakteristik Hakim dalam Gugatan Sederhana}

${ }^{14}$ Lihat Pasal 24 Perma Nomor 2 Tahun 2015 Tentang Tata Cara Penyelesaian Gugatan Sederhana.

${ }^{15}$ Hal ini akan menghindari dari kesan "ewuh pakewuh"ketika ternyata dalam pemeriksaan keberatan tersebut hakim bertentangan keputusannya.

${ }^{16}$ Lihat Pasal 25 Perma Nomor 2 Tahun 2015 Tentang Tata Cara Penyelesaian Gugatan Sederhana.

${ }^{17}$ Lihat Pasal 26 Perma Nomor 2 Tahun 2015 Tentang Tata Cara Penyelesaian Gugatan Sederhana. 
1) Dalam peradilan umum, asasnya Hakim bersifat pasif dan menunggu

Dalam hukum acara perdata, dikenal beberapa asas umum antara lain hakim bersifat menunggu dan hakim bersifat pasif. Hakim Bersifat Menunggu, artinya dalah bahwa pelaksanaanya, yaitu inisiatif untuk mengajukan tuntutan hak diserahkan sepenuhnya kepada yang berkepentingan.Kalau tidak ada tuntutan hak atau penuntutan, tidak ada hakim (nemo judex sine actore).Akan tetapi sekali perkara diiajukan kepadanya, hakim tidak boleh menolak untuk memeriksa dan mengadilinya, sekalipun dengan dalih bahwa hukum tidak atau kurang jelas ${ }^{18}$.Larangan untuk menolak memeriksa perkara disebabkan anggapan bahwa hakim tahu akan hukumnya (ius curia novit).

Sedangkan Hakim Pasif artinya dalam memeriksa perkara perdata bersikap pasif dalam arti kata bahwa ruang lingkup atau luas pokok sengketa yang diajukan kepada hakim untuk diperiksa pada asasnya ditentukan oleh para pihak yang berperkara dan bukan oleh hakim. Kedua asas ini wajib dipegang teguh, meskipun dalam beberapa tahapan, hakim tetap dituntut untuk bersikap aktif, misalnya ketika hakim wajib mengupayakan perdamaian.

2) Karakteristik Hakim dalam Gugatan Sederhana

Berbeda dengan karakteristik Hakim dalam gugatan perdata umum, dalam gugatan sederhana hakim wajib berperan aktif dalam persidangan. Hal tersebut secara eksplisit tertuang dalam Pasal 14 ayat (1) Perma Nomor $2 / 2015$, yang menyatakan bahwa dalam menyelesaikan gugatan sederhana, Hakim wajib berperan aktif dalam melakukan hal-hal sebagai berikut :

a) Memberikan penjelasan mengenai acara gugatan sederhana secara berimbang kepada para pihak.

${ }^{18}$ Lihat Pasal 10 ayat 1 UndangUndang Nomor 4 Tahun 2009 Tentang Kekuasaan Kehakiman.
Hal ini wajib dilakukan, mengingat bahwa Perma ini masih belum banyak dikenal oleh masyarakat luas. Selain itu banyak prosedur hukum acara yang ditentukan Perma ini yang menyimpangi prosedur hukum acara yang biasa, bahkan tidak menutut kemungkinan terdapat beberapa advokat yang masih belum memahami seluk beluk acara gugatan sederhana.

b) Mengupayakan penyelesaian perkara secara damai termasuk menyarankan kepada para pihak untuk melakukan perdamaian di luar persidangan.

Yang perlu diingat dalam memimpin tahapan ini adala hakim memperhatikan jangka waktu perdamaian yang menyimpangi jangka waktu mediasi yang diatur dalam Perma Mediasi. Selain itu, hakim tidak terikat pada perdamaian yang dilakukan diluar sidang sepanjang perdamaian itu tidak dilaporkan kepada hakim.

c) Menuntun para pihak dalam pembuktian

Peran aktif hakim juga dituntut dalam tahapan pembuktian, dimana hakim diwajibkan mengarahkan para pihak terhadap apa saja yang harus dibuktikan, karena hal tersebut akan meminimalisir terbuangnya waktu karena ketidak siapan para pihak dalam menyiapkan alat bukti. Serta mengefektifkan waktu agar para pihak dapat memberikan alat bukti yang releva terhadap pokok perkara.

d) Menjelaskan upaya hukum yang dapat ditempuh para pihak.

Jika dalam persidangan gugatan biasa, sifat pasif hakim ditunjukkan dengan hakim tidak boleh mengatur atau menentukan bahwa para pihak akan mengajukan banding atau tidak. Dalam gugatan sederhana, hakim wajib memberi penjelasan tentang upaya hukum keberatan yang bisa diajukan para pihak ketika tidak puas terhadap isi putusan.

Analisis Kelemahan PERMA 2Ttahun 2015 Tentang Tata Cara Penyelesaian Gugatan Sederhana.

Gugatan sederhana merupakan kewenangan Peradilan Umum, dalam Perma No. 2 Tahun 2015, sudah memebrikan limitasi 
kategori Gugatan Perdata yang dapat diajukan melalui mekanisme gugatan sederhana. Hal ini diatur dalam Pasal 3 dan 4, yang dapat disimpulkan :

1. Sengketa cidera janji/wanprestasi dan atau Gugatan Perbuatan Melawan Hukum yang nilai gugatan materiil maksimal 200 juta.

2. Bukan perkara yang masuk dalam kompetensi Pengadilan Khusus

3. Bukan sengketa hak atas tanah.

4. Penggugat dan Tergugat masing-masing tidak lebih dari satu, kecuali memiliki kepentingan hukum yang sama

5. Tempat tinggal tergugat diketahui

6. Penggugat dan Tergugat harus berdomisili di Daerah Hukum Pengadilan yang sama.

Syarat tersebut diatas bersifat komulatif dan limitatif, sehingga ketika satu syarat tidak dipenuhi maka perkara tersebut niscaya tidak akan bisa diselesaikan melalui mekanisme gugatan sederhana.

Selain syarat tersebut yang sering menjadi kendala penerapan gugatan sederhana dalam praktek, penulis menyimpulkan terdapat beberapa kelamahan norma yang terdapat dalam Perma tersebut, antara lain :

a. Kendala terkait dengan kedudukan para pihak yang tidak berada dalam domisili hukum yang sama.

Seperti yang telah penulis uraian sebelumnya, syarat untuk suatu perkara bisa dikategorikan sebagai perkara sederhana adalah bersifat fakultatif dari beberapa syarat yang sudah ditentukan oleh Perma ini salah satunya adalah para pihak tidak boleh berada dalam yuridiksi Pengadilan yang berbeda. Hal ini menimbulkan hambatan bagi para pihak yang kebetulan memilik perkara dengan nilai gugatan 200 juta akan tetapi kebetulan pihaknya berada dalam wilayah pengadilan yang berbeda.

b. Dalam mengajukan gugatan sederhana, para pihak bisa diwakili oleh kuasa hukum.

Hal ini berpotensi menimbulkan kendala atau permasalahan, karena bisa jadi, biaya atau ongkos yang harus dikeluarkan oleh para pihak sebagai honorarium kuasa hukum tidak sebanding dengan nilai gugatan. Hal tersebut akan secara tidak langsung mengurangi esensi gugatan sederhana.

c. Ruang lingkup/yurisdiksi gugatan sederhana hanya pada peradilan umum, tidak menjangkau Pengadilan Agama.

Pengadilan Agama adalah salah satu badan peradilan yang mengemban fungsi kekuasaan kehakiman untuk menyelenggarakan penegakkan hukum dan keadilan masyarakat, antara orang -orang yang beragama Islam di bidang perkawinan, waris, wasiat, hibah, wakaf, zakat, infaq, shadaqah dan ekonomi syariah. Kompetensi terakhir inilah yang kemudian bisa menimbulkan ketimpangan ketika perkara ekonomi syariha dengan nilai dibawah 200 juta tidak bisa ditangani dengan gugatan sederhana karena tunduk pada kompertensi pengadilan khusus.

d. Kedudukan hakim tunggal.

Dalam UU No. 48 Tahun 2009 Tentang Kekuasaan Kehakiman mengatur bahwa pemeriksaan dilakukan dengan hakim majelis, hal ini salah satunya bertujuan untuk menjaga obyektifitas dalam putusan hakim dan diharapkan agar putusan yang dihasilkan telah disertai pertimbangan hukum yang cermat dan hati-hati. Sedangkan dalam gugatan sederhana hakimnya merupakan hakim tunggal. Di satu sisi, hal ini akan menyederhanakan proses pemeriksaan, tetapi disisi lain juga berpotensi menimbulkan putusan yang kurang memenuhi asas keadilan ketika subyektifitas lah yang dikedepankan oleh hakim yang bersangkutan dalam memeriksa perkara.

Masalah-masalah peradilan yang cepat biaya ringan mengatur tentang hal-hal yang sifatnya eksteren, tidak berhubungan dan tidak menyentuh isi serta inti perkara itu sendiri. Sebagaimana yang penulis sudah nyatakan diatas, sifat pemeriksaan yang sederhana, cepat dan biaya ringan tidak boleh mengorbankan kecermatan serta ketelitian penanganan suatu perkara. Pasal 1 UU Pokok Kekuasaan Kehakiman menentukan bahwa kekuasan kehakiman adalah kekuasaan negara yang merdeka untuk menyelenggarakan peradilan gula menegakkan hukum dan keadilan. Hukum 
hanya bisa ditegakkan dan keadilan hanya bisa dirasakan apabila proses pemeriksaan di depan pengadilan dilakukan dengan kecermatan dan ketelitian, sehingga dihasilkan putusan yang secara kualitatif benar bermutu dan memenuhi rasa keadilan masyarakat.

Untuk mengatasi hal tersebut, menurut Prof. Mr. Henc van Maarseveen, adalah hakim memperhatikan asas-asas umum peradilan yang baik, khususnya dalam 2 (dua) asas sebagai berikut :19

\section{1) Sikap Cermat dan Hati-hati}

Dituntut pada seorang hakim suatu upaya untuk bertindak cermat dan hati-hati (zorgvuldig handelen). Sikap cermat serta hatihati meliputi upaya untuk selalu mendengar kedua belah pihak, memperhatikan hak-hak untuk pembelaan diri, mencegah penyalahgunaan hukum acara, upaya untuk menjatuhkan putusan tepat pada waktunya, upaya untuk bersikap tidak memihak/parsial, serta tidak menguntungkan salah satu pihak yang berperkara.

2) Hakim harus memberikan pertimbangan yang cukup dalam setiap putusannya.

Dalam membuat putusan, Hakim disyaratkan memberikan argumentasi bagi yang jelas pada putusannya, tidak berlaku otoriter. Argumentasi yang jelas dan sistematis bagi para pihak maupun pencari keadilan pada umunya, tentang apa alasan dia memutus demikian serta mengapa dia tidak memberi putusan yang berbeda dengan putusan yang dia jatuhkan. Hal ini dikenal dengan istilah motiveringsplicht.

Motiveringsplich yang dasar-dasarnya diletakkan oleh Pasal 23 UU Pokok Kekuasaan Kehakiman, telah dikukuhkan oleh Yurisprudensi Mahkamah Agung dalam putusannya tertanggal 22 Juli 1970 No. 638 K/Sip/1969, yang menyatakan bahwa putusanputusan Pengadilan Negeri dan Pengadilan Tinggi yang kurang cukup dipertimbangkan (onvoldoende gemotiveerd) harus dibatalkan.

${ }^{19}$ Setiawan, “Aneka Masalah Hukum dan Hukum Acara Perdata”, Alumni, Jakarta, 1992, hlm. 427 . e. Dalam Perma tidak diatur tentang konsekwensi ketika putusan melebihi waktu 25 hari.

Sehingga akan memungkinkan terjadinya ketidak pastian hukum apa yang akan terjadi terhadap putusan ketika melewati jangka waktu 25 hari. Apakah putusan batal demi hukum, hal tersebut tidak diatur dalam Perma.

\section{f. Pembuktian sederhana dalam Perma.}

Pada dasarnya hukum acara perdata adalah hukum formil yang kental dengan prosedur yang sifatnya rigid dan terkadang tidak bisa disimpagi. Demikian juga pada saat tahapan pembuktian. Perma menentukan bahwa pemeriksaan dilakukan dengan pembutian sederhana, akan tetapi di dalam perma tidak dijelaskan tentang pembutian sederhana yang bagaimana yang dimaksud. Selama ini pembuktian sederhana dikenal dalam lapangan hukum kepailitan.

Pembuktian sederhana dalam kepailitan, terdapat dalam Pasal 8 ayat (4) UU Kepailitan sebagai berikut:

"Permohonan pernyataan pailit harus dikabulkan apabila terdapat fakta atau keadaan yang terbukti secara sederhana bahwa persyaratan untuk dinyatakan pailit sebagaimana dimaksud dalam Pasal 2 ayat (1) telah dipenuhi."

Merujuk pada ketentuan tersebut, jelas bahwa yang harus dibuktikan secara sederhana adalah syarat kepailitan dalam Pasal 2 ayat (1) UU Kepailitan, yaitu:

1. Ada dua atau lebih kreditor. Kreditor adalah orang yang mempunyai piutang karena perjanjian atau undang-undang yang dapat ditagih di muka pengadilan. "Kreditor" di sini mencakup baik kreditor konkuren, kreditor separatis maupun kreditor preferen.

2. Ada utang yang telah jatuh waktu dan dapat ditagih yang tidak dibayar lunas oleh debitor. Artinya adalah ada kewajiban untuk membayar utang yang telah jatuh waktu, baik karena telah 
diperjanjikan, karena percepatan waktu penagihannya sebagaimana diperjanjikang. karena pengenaan sanksi atau denda oleh instansi yang berwenang, maupun karena putusan pengadilan, arbiter, atau majelis arbitrase.

Yang dimaksud dengan "fakta atau keadaan yang terbukti secara sederhana"? Yang dimaksud dengan "fakta atau keadaan yang terbukti secara sederhana" adalah adanya fakta dua atau lebih kreditor dan fakta utang yang telah jatuh waktu dan tidak dibayar. Sedangkan perbedaan besarnya jumlah utang yang didalihkan oleh pemohon pailit dan termohon pailit tidak menghalangi dijatuhkannya putusan pernyataan pailit.

Dengan tidak dijelaskan apa yang dimaksud dengan pembuktian sederhana, para pihak kemudian tergantung sepenuhnya pada arahan hakim untuk menentukan alat bukti apa yang seyogyanya diajukan.

duplik dan kesimpulan, Penulis sepaham untuk acara ini ditiadakan, karena seringkali dalam pratek digunakan para pihak yang tidak memiliki itikad baik untuk sengaja mengulur-ulur jalannya persidangan.

\section{h. Tidak diatur mengenai sita jaminan}

Dalam gugatan sederhana sekalipun ada kemungkina pihak Tergugat memiliki itikad buruk mengalihkan aset selama pemeriksaan. Dengan tidak diaturnya keberadaan sita jaminan, maka hal ini menimbulkan persoalan, apakah diserahkan kepada Hakim yang memeriksa perkara, yang akan menilai relevansi permohonan sita jaminan tersebut. Atau dengan kata lain Hakim menundukkan diri pada hukum acara perdata yang berlaku secara umum.

\section{PENUTUP}

1. Perma No. 2 Tahun 2015 sebagai salah satu instrumen penerapan asas peradilan sederhana, cepat, biaya ringan. Hal tersebut ditandai dengan beberapa pengaturan yang mebedakan dengan gugatan perdata umum, antara lain : Pemeriksaan gugatan sederhana dilakukan
Mengingat singkatnya jangka waktu pemeriksaan gugatan sederhana, maka dalam Perma ini melarang para pihak mengajukan tuntutan provisi, eksepsi, rekonvensi, intervensi, replik, duplik, atau kesimpulan.

Hal ini akan menimbulkan persoalan khususnya dengan dilaran diajukannya eksepsi oleh Tergugat. Sifat larangan ini bisa menciderai hak Tergugat. Sebagaimana diketahui eksepsi adalah bantahan Tergugat yang tidak terkait dengan pokok perkara. Jika Tergugat beranggapan bahwa gugatan bukan merupakan kategori gugatan sederhana, melainkan harus diperiksa dalam proses gugatan biasa, maka Tergugat seyogyanya membuktikan hal tersebut dan memberi bantahan. Misalnya terkait dengan error in persona maupun tidak terpenuhinya legal standy Penggugat. Sedangkan untuk gugatan provisi, gugatan rekovensi, replik, oleh hakim tunggal, para pihak dalam gugatan sederhana tidak boleh lebih dari satu dan berdomisili di daerah hukum Pengadilan yang sama, pemeriksaan gugatan sederhana hanya dalam tempo 25 hari. Dalam gugatan sederhana hakim wajib berperan aktif dalam persidangan.

2. Disisi lain, Perma Nomor 2 Tahun 2015 memiliki beberapa kelamahan norma antara lain : Kendala terkait dengan kedudukan para pihak yang tidak berada dalam domisili hukum yang sama, dalam mengajukan gugatan sederhana, para pihak bisa diwakili oleh kuasa hukum, ruang lingkup/yurisdiksi gugatan sederhana hanya pada peradilan umum, tidak menjangkau Pengadilan Agama, kedudukan hakim tunggal berpotensi mempengaruhi subyektifitas hakim, tidak diatur tentang konsekwensi ketika putusan melebihi waktu 25 hari., belum ada ketentuan yang jelas mengenai Pembuktian sederhana, tidak diperkenankannya eksepsi serta belum ada ketentuan mengenai sita jaminan. Hal tersebut akan menimbulkan ketidak pastian hukum dalam penerapan gugatan sederhana. 


\section{Saran}

1. Salah satu penyebab masih belum optimalnya Perma Nomor 1 Tahun 2015 adalah kurangnya sosialisasi keberadaan Perma ini kepada masyarakat, oleh sebab itu maka pihakpihak terkait seyogyangnya lebih mengoptimalkan sosialisasi dengan harapan masyarakat mengetahui dan memahami prosedur penyelesaian gugatan sederhana.

2. Mahkamah Agung harus mulai mengkaji kembali beberapa syarat gugatan sederhana antara lain syarat mengenai domisili para pihak yang harus berada dalam wilayah hukum yang sama serta apakah perma ini juga dapat diberlakukan pada sengket syariah di pengadilan agama.

3. Bagi para advokat, hendaknya mengoptimalkan peranannya dalam melakukan pendampingan gugatan sederhana tanpa mengedepankan unsur materi yang berlebihan.

4. Bagi hakim yang memutus perkara sederhana, hendaknya menjalankan pemeriksaan dengan tetap mengedepankan kecermatan dan pertimbangan yang cukup guna memenuhi asas keadilan bagi masyarakat.

\section{DAFTAR PUSTAKA}

\section{Literature}

Anita D.A. Kolopaking, "Asas Itikad Baik Dalam Penyelesaian Sengketa Kontrak Melalui Arbitrase", Alumni, Jakarta, 2013.

Bambang Sutiyoso, "Penyelesaian Sengketa Bisnis; Solusi dan Antisipasi bagi Peminat Bisnis dalam Menghadapi Sengketa Kini dan Mendatang" Citra Media, Yogjakarta, 2006.

D.Y. Witanto, "Hukum Acara Mediasi", Alfabeta, Bandung, 2010.

Efa Laela Fakhriah, "Bukti Elektronik dalam Sistem Pembuktian Perdata", Alumni, Bandung, 2011.
Efa Laela Fakhriah, "Perbandingan HIR dan RBG Sebagai Hukum Acara Perdata Positif di Indonesia", Keni Media, Bandung, 2015.

M. Yahya Harahap, "Kekuasan Pengadilan Tinggi dan Proses Pemeriksaan Perkara Perdata Dalam Tingkat Banding”, Sinar Grafika, Jakarta, 2005.

"Hukum Acara Perdata Tentang Gugatan, Persidangan, Penyitaan, Pembuktian dan Putusan Pengadilan", Sinar Grafika, Jakarta, 2004, hlm. 233

Rahmadi Usman, "Mediasi di Pengadilan Dalam Teori dan Praktik", Sinar Grafika, Jakarta, 2012. "Penyelesaian Sengketa di Luar Pengadilan", Citra Aditya Bakti, bandung.

Setiawan, "Aneka Masalah Hukum dan Hukum Acara Perdata", Alumni, Jakarta, 1992.

Sophar Maru Hutagalung, "Praktik Peradilan Perdata dan Alternatif Penyelesaian Sengketa”, Sinar Grafika, Jakarta, 2012.

Sudiarto, "Negosiasi, Mediasi dan Arbitrase, Penyelesaian Sengketa Alternatif di Indonesia”, Pustaka Reka Cipta, Bandung, 2013.

Sudikno Mertokusumo, Hukum Acara Perdata Indonesia, edisi keenam, Liberty, Yogyakarta, 2006.

"Hukum Acara Perdata-Edisi Revisi", Cahaya Atma Pustaka, Yogyakarta, 2010.

Suyud Margono, "Penyelesaian Sengketa Bisnis, Alternatif Dispute Resolution (ADR), Teknik \& Strategi dalam Negosiasi, Mediasi \& Arebitrase", Ghalia Indonesia, Bogor, 2010.

Zainuddin Ali, "Metode Penelitian Hukum", Sinar Grafika, Jakarta, 2009.

\section{Peraturan perundang-undangan}

1. Undang-Undang Nomor 48 Tahun 2009 Tentang Kekuasaan Kehakiman.

2. Het Herzeine Indonesisch Reglement (HIR). 
3. Peraturan Mahmakah Agung Nomor 2

Tahun 2015 Tentang Tata Cara

Penyelesaian Gugatan Sederhana.

\section{Jurnal}

Efa Laila Fakhriah, Mekanisme Small Claim's

Court Dalam Mewujudkan Peradilan

Sederhana, Cepat, dan Biaya Ringan,

Mimbar Hukum Volume 25, No. 2,

Juni 2013.

Kurniawan,Perbandingan Penyelesaian

Sengketa Konsumen di Indonesia

dengan Negera-negara Common Law

System, Jurnal Hukum dan

Pembangunan, Tahun ke 44, No-2,

Edisi April-Juni 2014.

\section{Artikel Internet}

Urgensi Terbitnya Perma Small Claim Court,

Hukumonline.com, diakses pada tanggal 15 Maret 2017.

Bustamar, Small Claim Court dalam Hukum Acara Perdata di Indonesia, diakses tanggal 15 Maret 2017. 
